\title{
SOCIAL INNOVATIONS IN THE PROFESSIONAL TRAINING OF MANAGERS UNDER THE CONDITIONS OF KNOWLEDGE ECONOMY DEVELOPMENT
}

\author{
Natalia Mushynska', Marianna Kniazian²
}

\begin{abstract}
The transformation in the system of business relations in modern times has led to the formation of the economy based on knowledge. Relevant processes place qualitatively new demands to the managerial staff in this system and, consequently, to the technologies of their professional training. Effective usage of innovations in pedagogy for the training of managers becomes one of the fundamental factors in the formation of competitiveness of knowledge economy. The purpose of the paper is to reveal the essential characteristics, generalization and justification of social and pedagogical innovations in the professional training of managers under the conditions of the formation of a knowledge economy. The methodological principles, which the given analysis is based on, include the implementation of a set of universal and special methods of scientific cognition. Results. The role of education is defined as the foundation for the economy based on knowledge. In total, it is possible to distinguish three main areas for optimization of the process of professional and personal development of future managers: expanded implementation to the system of in-class activities forms, methods and technologies that teach to perform practically all managerial functions and actions under different market conditions; implementation to the educational institution of out-of-class forms of practical work that develop market and managerial thinking and other qualities, skills, and abilities; expansion of personality developing space in the educational institution. So, in the context of the knowledge economy formation, important means for the development of managers' economic knowledge are those that are aimed at studying, analysing the achievements of economic thought, understanding information, and generating their own effective options for management optimization. Based on this, the priority social and pedagogical innovations are: projecting and modelling in management, research, and creative activity. Practical implications. In the project process, a clear formulation of the project's goals and objectives, development of the final material product (business plan; measures to optimize management of a certain enterprise sector; a set of diagnostic methods for assessing the professional competence of applicants for the position, etc.) were assumed. Modelling allowed developing and exploring models of objects of economic activity, which helped to systematize knowledge about them, to specify their components, to disclose new functions. Research and creative activity allowed students to study at the empirical and theoretical levels in the economic sphere, the laws of its phenomena functioning in the context of their systemic interconnection with the goal of knowledge development about it, generating and implementing effective approaches to solve problems.
\end{abstract}

Key words: knowledge economy, social and pedagogical innovations, projecting, modelling, research and creative activity, training of managers.

JEL Classification: A10, A29, I23, M54

\section{Introduction}

In modern times, in most countries of the world, there are radical changes in the functioning of national economy: the scale of international commodity flows is expanding, the process of globalization is boosting, the level of national wealth is increasing. The integration of economy at the regional and national levels, which is promoted by the development of communication and information technologies, changes the nature of speciality in the global economy, promotes the development of offshore, relocation of finished goods production and provision of services to regions with low costs. Globalization is gradually changing the picture of the world, and in addition to positive changes, there are a number of challenges:

\footnotetext{
Corresponding author:

${ }^{1}$ Odesa Institute of Trade and Economics

of Kyiv National University of Trade and Economics, Ukraine.

E-mail: ameline@ukr.net

${ }^{2}$ Odessa I.I. Mechnikov National University, Ukraine.

E-mail: kniazian1970@gmail.com
} 
increasing the vulnerability of workers, slowing down the growth in the number of working places and reducing the overall share of wages in national income.

The most effective response to these challenges is the spread of knowledge that is steadily leading to the developmentofthenational economy. Knowledgebecomes the main driving force of increasing productivity (Koval et al., 2018), as well as a source of high-quality economic growth. Knowledge and innovation are becoming more and more important for companies engaged in various types of economic activity. In turn, it puts the countries in charge of forming the basic factors that influence the process of generating knowledge in the economy. First of all, this is the development of human capital and education. Employment in the knowledge economy is determined by the increase in the value of skilled labour, and the political course of many countries is increasingly focusing on the development of human capital.

Education becomes an integral part of further development of the innovation sector, human potential and successful employment of professionals under the conditions of an economy based on knowledge. First of all, it concerns the training of future managers in the business sector, which will operate under fundamentally new conditions of the knowledge economy. This determines the actuality to define prospective social and pedagogical means directed to the quality improvement and adaptation of professional training of managers to the new conditions of the global economy functioning.

\section{Analysis of recent researches and publications}

A number of national scientists devoted their scientific works to the research of innovations in the training of managers (Bereka, 2009; Elkin, 2013; Pshenychna, 2016; Tereshchenko, 2016; Zhukov \& Kobal, 2017; Vorona, 2017). These authors in their works analyse the interdependence between the formation of an innovative model of the economy, the development of the system of professional training for management of innovative activities and the increase in the efficiency of enterprises; consider the problems and perspectives of modernization in training of managers in the context of innovative reformation of the education system in modern Ukraine. Great attention is paid to the latest methods of managers' training with the use of developing and contextual technologies to educate higher education graduates.

The principal attention is paid to the problem of the formation of key competencies of future specialist in economics (Grant, 2005), among which the most important, according to the scientist, is the ability "to communicate quite complex ideas and theories in a clear manner, undertake numerical calculations, and interpret data presented in a variety of forms." Scientists (Dusi et al, 2014; Korniyaka, 2018) emphasize on the necessity to form reflexiveness, positive attitude towards others, and the ability to communicate effectively as an inevitable requirement for the personality of modern specialist working in a multicultural society. Of great significance is also the study of the role of emotions in the development of professional and reflexive views of future professionals, including economists (Rezvan, 2014; Shymko, 2017).

While considering the existing scientific works of great importance, it should be noted that the study of pedagogical mechanisms of professional training of managers who take into account the specifics of management activity in the context of the formation of the knowledge economy has still been paid insignificant attention. This leads to the necessity for further scientific research in the actualized problem.

The purpose of the study is to reveal the essential characteristics, generalization and justification of social and pedagogical innovations in the professional training of managers in the conditions of the formation of the economy based on knowledge.

\section{Peculiarities of formation of the knowledge economy in modern conditions}

The formation of the knowledge economy involves the transition from one state to another, higher, more qualitative and progressive. The development of knowledge, from our point of view, provides for their systematic expansion, rethinking and interpretation, which serves to solve modern problems in the economic sphere in order to ensure stable growth of the economy and the well-being of society.

The foundation of the modern knowledge economy is qualitative education, which is given a priority role, since it becomes the basis for building a fundamentally new type of society, where the competition of knowledge becomes the driving force of the economy. Increasing volumes of monetary resources in leading countries of the world are aimed at training specialized specialists and researches, which allows maintaining a high level of competitiveness of economies in the international arena. Highly-educated specialists become the basis for the formation of leading sectors of the national economy, where the highest level of labour productivity is observed, creating the largest volumes of added value. These sectors of the economy include, in particular, the information and communication technology sector (ICT), which makes a major contribution to welfare growth (Table 1).

In order to achieve the level of advanced countries development in the formation of the knowledge economy, it is necessary for education not only to give knowledge and skills but, above all, to create innovations that will have the potential for commercialization of them in the form of new goods and services.

In Ukraine, in 2017, the share of the research workers (researchers, technicians, and support staff) in the total number of employed population was $0.58 \%$, including researchers $-0.37 \%$. According to Eurostat, in 2015, the highest share was in Finland (3.21\% and 2.35\%), Austria 
Table 1

Dynamic transition to the economy, based on knowledge, in OECD countries

\begin{tabular}{|c|c|c|c|c|c|c|}
\hline Indicators & 1995 & 2000 & 2005 & 2010 & 2015 & 2017 \\
\hline GDP per capita according to PPP, thousands US dollars in prices in 2011 & 28,7 & 32,8 & 35,4 & 36,0 & 38,4 & 39,6 \\
\hline R\&D expenditures, $\%$ of GDP & 2,12 & 2,27 & 2,20 & 2,36 & 2,45 & 2,49 \\
\hline Number of researchers, thousand people per million population & 2,47 & 2,69 & 3,09 & 3,34 & 4,05 & - \\
\hline Share of services in the field of ICT in the total export of services, $\%$ & 2,94 & 5,49 & 6,97 & 7,92 & 7,66 & 9,79 \\
\hline Income of payments balance from the copyright usage, billion dollars of the USA & 46,6 & 91,2 & 167,6 & 242,9 & 315,1 & 336,1 \\
\hline
\end{tabular}

Source: made by the authors according to the World Bank (2018)

(3.10\% and $1.92 \%)$, and Sweden $(2.97 \%$ and $2.33 \%)$; the lowest share was in Romania (0.53\% and $0.33 \%)$, Cyprus (0.83\% and $0.61 \%)$, Poland $(1.0 \%$ and $075 \%)$, and Bulgaria (1.0\% and $0.65 \%)$. The share of doctors of sciences and doctors of philosophy (candidates of science) among the scientists of the Research Institute was $27.7 \%$, among researchers $-43.8 \%$.

More than half of the total number ofDoctors ofSciences and Doctors of Philosophy (Candidates of Science), who carried out research and development, worked in organizations of the state sector of the economy, $36.1 \%$ higher education, 5.4\% - entrepreneurship sector.

According to preliminary calculations, the share of total expenditures in GDP was $0.45 \%$, including at the expense of the state budget $-0.16 \%$. According to 2016, the share of expenditures on research and development in the GDP of the EU-28 countries averaged $2.03 \%$. More than the average share of research and development costs was in Sweden - 3.25\%, Austria - 3.09\%, Germany - 2.94\%, Denmark - 2.87\%, Finland-2.75\%,Belgium-2.49\%,France-2.25\%; smallerin Macedonia, Latvia, Romania, Cyprus, and Malta (from $0.43 \%$ to $0.61 \%$ ).

Currently, in countries with a developed market economy, production of knowledge and high technology serves as the main source of economic growth. However, knowledge doesn't often bring revenue. As a rule, they are realized in the form of innovations. A key tool for the practical implementation of new knowledge and technologies is the general national innovation system.

Table 2

Financing of internal expenditures for research and development activities in different sectors in Ukraine

\begin{tabular}{|c|c|c|c|}
\hline & 2015 & 2016 & 2017 \\
\hline Total & 11001889,5 & 11530697,5 & 13379292,4 \\
\hline \multicolumn{4}{|c|}{ according to activity sectors } \\
\hline state & 3728725,8 & 3672219,4 & 7788641,7 \\
\hline entrepreneurship & 6682532,1 & 7132981,8 & 4614846,4 \\
\hline higher education & 590631,6 & 725496,3 & 975804,3 \\
\hline private non-profit & - & - & - \\
\hline
\end{tabular}

Source: made by the authors according to the State Statistics Service of Ukraine (2018)

Table 3

The specific weight of expenses for research and development in GDP

\begin{tabular}{|l|c|c|c|c|c|c|c|c|}
\hline \multicolumn{1}{|c|}{ Countries } & 2010 & 2011 & 2012 & 2013 & 2014 & 2015 & 2016 & 2017 \\
\hline EU 28 & 1,93 & 1,97 & 2,01 & 2,02 & 2,03 & 2,04 & 2,03 & $\ldots$ \\
\hline Bulgaria & 0,56 & 0,53 & 0,60 & 0,63 & 0,79 & 0,96 & 0,78 & $\ldots$ \\
\hline Estonia & 1,58 & 2,31 & 2,12 & 1,72 & 1,45 & 1,49 & 1,28 & $\ldots$ \\
\hline Spain & 1,35 & 1,33 & 1,29 & 1,27 & 1,24 & 1,22 & 1,19 & $\ldots$ \\
\hline Latvia & 0,61 & 0,70 & 0,66 & 0,61 & 0,69 & 0,63 & 0,44 & $\ldots$ \\
\hline Lithuania & 0,78 & 0,90 & 0,89 & 0,95 & 1,03 & 1,04 & 0,85 & $\ldots$ \\
\hline Germany & 2,71 & 2,80 & 2,87 & 2,82 & 2,87 & 2,92 & 2,94 & $\ldots$ \\
\hline Poland & 0,72 & 0,75 & 0,88 & 0,87 & 0,94 & 1,00 & 0,97 & $\ldots$ \\
\hline Romania & 0,46 & 0,50 & 0,48 & 0,39 & 0,38 & 0,49 & 0,48 & $\ldots$ \\
\hline Slovakia & 0,62 & 0,66 & 0,80 & 0,82 & 0,88 & 1,18 & 0,79 & $\ldots$ \\
\hline Slovenia & 2,06 & 2,42 & 2,57 & 2,58 & 2,37 & 2,20 & 2,00 & $\ldots$ \\
\hline Hungary & 1,15 & 1,19 & 1,26 & 1,39 & 1,35 & 1,36 & 1,21 & $\ldots$ \\
\hline Czech Republic & 1,34 & 1,56 & 1,78 & 1,90 & 1,97 & 1,93 & 1,68 & $\ldots$ \\
\hline Ukraine & 0,75 & 0,65 & 0,67 & 0,70 & 0,60 & 0,55 & 0,48 & 0,45 \\
\hline
\end{tabular}

Source: made by the authors according to the State Statistics Service of Ukraine (2018) 
The primary and most important goal of creating such a system is to develop the process of formation and introduction of innovations, which requires the use of social and pedagogical innovations in professional training of highly skilled specialists in the sphere of management.

Innovation is a system of means directed for implementation into the economy of certain methods and technologies, which have the aim to increase the efficiency of the operation of an enterprise, company, industry. Social and pedagogical innovations are innovations directed for the improvement of the quality of the content, organization, management of education. In our opinion, these innovations in the development of economic knowledge serve for the growth of information, its analysis, systematization, and interpretation. It is important that this knowledge differs with prognostic nature, helps not only to solve modern problems but also to make the basement for foreseeing and solving possible problems in the future.

Pedagogical innovations are a kind of social innovations that are related to the educational process in order to achieve maximum results and include the development of a system of principles and criteria, quality assessment of realization of the educational process, the implementation of new approaches to the system of professional training of managers.

In the context of the formation of knowledge economy, special importance in professional training of managers is given to innovative activity, which is directed to the implementation of various pedagogical innovations that cover all aspects of the didactic process: forms of organization of educational process, the content and technologies of learning, educational and cognitive activities. An important means of development of economicknowledge ofmanagers are those that are aimed at studying, analysing the achievements of economic thought, understanding information, generating own effective options for management optimization.

Changes in education role in our society along with the development of the knowledge economy have led to the growth of innovation processes in the professional training of managers and education in general. From a passive process carried out in traditional social institutions, education is acquiring an active character. Previously, the unmistakable orientation of education was the formation of knowledge, skills, abilities, which ensure readiness for the fulfilment of managerial responsibilities and were understood as the ability of individual for adaptation in community. Nowadays, education is increasingly oriented to the creation of such technologies and methods of influence on personality, which provide a balance between the social and individual needs of a specialist, launch the mechanism of personality self-development thus training them for the realization of his own personality in the process of performing managerial functions.

\section{Knowledge management in an innovative system of education of managers in the transition to a knowledge economy}

In the educational process, it should be taken into account that the formation of a knowledge economy influenced the increase of the requirements to all aspects of a manager's personality, and not only to their individual qualities. A common type of new managers becomes "mobile" performers or "ordinary" entrepreneurs who create a new business. A more successful model is a specialist who is able to draw conclusions and is able to raise the company in the state of crisis. Modern effective management involves the ability to communicate, be accessible, encourage and accept the flow of ideas, demonstrate flexibility in behaviour. The results of large-scale research conducted in recent years show that the managers of the XXI century should possess: good preparation for strategic planning; acceptance of changes and their management; the ability to manage quality systematically; the skill of communication; readiness for mentoring and supporting; the ability to delegate responsibility correctly (Pikalov \& Hlukha, 2017).

The fundamental transformation of national economic systems under the conditions of development of knowledge economy sets the task to construct the educational process in accordance with qualitatively new principles, which go beyond not only knowledge formation but also the development of skills and abilities. Today, the successful solution of the task of professional manager formation requires:

- purpose acceptance by the educational institution as the main one;

- organization of scientific and pedagogical staff activities and activities of other permanent staff for the comprehensive formation of future specialists as managers, professionals, and individuals;

- organization of work of future managers for selfformation as professional individuals;

- creation in an educational institution of supportive social and psychological climate and suitable conditions for the proper professional development of personality of future managers;

- organization of current control and progress check of the course and results of professional development of personality of graduates as managers.

In total, it is possible to distinguish three main directions of optimization of the process of professional and personal formation of future managers: extended inclusion in the system of classroom studies of forms, methods, and technologies that teach to perform all managerial functions and actions practically in different market conditions; the inclusion in educational institution of out-of-class forms of practical work that develop market and managerial thinking and other qualities, skills, and abilities; the expansion of personality forming space 
of educational institution through the organization of continuous industrial practice.

On this basis, priority social and pedagogical innovations are projecting and modelling in management, research and creative activity. It should be noted that these innovations in professional training of managers are realized, first of all, through interactive technologies and computer technologies.

\section{Social and pedagogical innovations in the professional training of managers}

An important social and pedagogical innovation in the development of economic knowledge is project activity, which involves conducting a certain search and study of theoretical information. The project assumes the following: clear formulation of the purpose and objectives of the project; search for necessary knowledge to solve project tasks; planning and fulfilment of concrete actions for its implementation, indicating the deadlines for each action; development of the final material product (business plan; measures systems for optimization of management of the enterprise certain sector; a set of diagnostic methods for assessing the professional competence of applicants for a position, etc.); drawing of conclusions.

Modelling allows us to develop and explore models of objects of economic activity, which helps to systematize knowledge about them, to specify their components, to reveal new functions.

In the humanities, the structure of the model is represented by interconnected segments, among which the following are obligatory: goal-oriented (representation of purpose); methodological (theoretical basis (scientific approaches and principles)); structural (components of the object); functional-diagnostic (stages of functioning of the studied object and their monitoring).

The development of models in the management sphere allows significant expansion of concepts about certain phenomena, processes, objects, and optimization of their functioning for the benefit of our society.

Innovation in research and creative activity is explained by two factors: firstly, the volume of information is dynamically increasing; accordingly, in order to be aware of the latest achievements in management sphere, it is necessary to be able to process it (to select, analyse, classify) quickly and implement it relatively to the solution of specific problems; secondly, the efficiency of the enterprise operation mostly depends on the manager's ability to generate, test, and implement innovations.

Research and creative activity infers studying at the empirical and theoretical levels of the economic sphere, functional regularities of its phenomena in the context of their systematic interconnection with the purpose of knowledge development about it, generating and implementing effective approaches for problems solutions.

This activity may have an objective to obtain subjectively or objectively new knowledge about management sphere, where subjectively new knowledge is new to the researcher of a particular problem, and objectively new one is the knowledge that differs in social significance and, finally, defines the effectiveness of enterprise operation.

In the management sphere, research and creative activity, as a means of development of economic knowledge, is reasonable to organize in accordance with the following steps:

- allocation among the problems of the main and secondary ones; setting the goal; development of a logically consistent, flexible plan and selection of effective research methods;

- study of the necessary theoretical information, presenting of its annotation and abstract; consulting with professionals about this problem;

- generation of original ideas on how to solve the problem, selection of the most effective ones, their argumentation, preliminary approbation with subsequent implementation into practice;

- conducting empirical research (observations, expert assessment, surveys, etc.); the processing of the received information, its analysis, comparison of various facts; - comparison of results of the experiment with the theory; generalization of research results; drawing of conclusions and recommendations; forecasting of possible variants of development of the studied phenomena.

Research and creative activity allows developing economic knowledge in the most active way, both for personal development (knowledge of a specific manager) and social development (potential growth of progressive management experience of an enterprise, firm, company).

We have conducted a study of 112 students (63 girls and 49 boys) to indicate their interest in each defined social and pedagogical innovations in the process of their professional training as managers. Students were asked the question "Which social and pedagogical innovations suggested below are of greatest interest to you: projecting, modelling, research, or creative activity?" The results were categorized according to the gender of the students. The data is presented in Table 4.

Table 4

Indication of students' interest in social and pedagogical innovations

\begin{tabular}{|c|c|c|c|}
\hline \multirow{2}{*}{$\begin{array}{c}\text { Social and pedagogical } \\
\text { innovations }\end{array}$} & \multicolumn{2}{|c|}{$\begin{array}{c}\text { Number of students. } \\
\text { Gender }\end{array}$} & \multirow{2}{*}{ Total } \\
\cline { 2 - 3 } & Female & Male & \\
\hline Projecting & $33.3 \%$ & $34.7 \%$ & $68.0 \%$ \\
\hline Modelling & $27.0 \%$ & $38.8 \%$ & $65.8 \%$ \\
\hline Research and creative activity & $39.7 \%$ & $26.5 \%$ & $66.2 \%$ \\
\hline Total & $100 \%$ & $100 \%$ & \\
\hline
\end{tabular}


The greatest girls' interest is caused by research and creative activity (39.7\%), whereas for boys it is modelling (38.8\%). At the same time, it is necessary to emphasize that modelling causes the least interest among girls $(27.0 \%)$. In the second position of interest indicating, both girls and boys turned out to be interested in designing (33.3\% were among girls interested in designing, and $34.7 \%$ - among boys). The smallest number of boys (26.5\%) indicated that their research and creative activity was of the greatest interest to them. As a result, the largest number of students $(68.0 \%)$ shows the highest interest in designing, $66.2 \%$ - in research and creative activity, $65.8 \%$ - in modelling. These results indicate the necessity to increase the interest of students in modelling as an important social and pedagogical innovation in the professional training of managers.

It should be emphasized that the complex of qualities that should be developed by future managers in order to prepare them for professional activity under the conditions of knowledge economy must include: the ability to conduct a qualitative independent analysis of economic realities; awareness of the possibilities of your personal career; knowledge of national economy; the ability to cherish the workplace, an understanding that it is not guaranteed for life; modern economic thinking, ability to conduct economic calculations within the limits of the activity and personal life; curiosity, ability to acquire knowledge, acquire skills in self-study and career enhancement; personal qualities: honesty, conscientiousness, proficiency, initiative, responsibility, professional flexibility; ability to work in a group, skills of business communication; communication skills in industry, trade, business, commerce; friendliness, as a basis for success in relationships, politeness, sincerity, attentiveness, motoriness; the ability to assess statistical data in the press, understand economic tables and graphs; ability to analyse, generalize, identify, apply knowledge in a dynamically changing environment (Seliverstova, 2010).

At the same time, pedagogical innovations should not lose sight of the development of general business skills in professional training of managers. These abilities include the ability: to determine the real goals for oneself, to calculate the path to those goals that are difficult to reach by one-time effort; analyse situations and problems; nominate professionally and scientifically substantiated versions of the origin of the problem and the ways of its solution; anticipate difficulties in problem-solving; outline ways and means to solve the problem and compare them with their capabilities (experience, training, qualities, abilities, skills, time, etc.); make decisions based on choosing one solution from a number of possible ones, calculate stages and methods of implementation, means of provision, immediate results, possible side effects and long-term consequences; self-critically evaluate the correctness of the chosen solution and the calculation of its implementation; control the progress of the decision, evaluate the intermediate results and the success in movement to final goal.

Mastering the profession of a manager under the conditions of formation of the knowledge economy is an important stage of professional self-determination. No one can make a person the one he/she does not want to be. Everyone becomes a professional in that way as they have created themselves as professionals. Studying in a professional institution is the right time and place to create ourselves as a professional. Introduced social and pedagogical innovations should give future managers a clear understanding of this and a strong motivation for professional self-improvement, comprehensively strengthen discipline, intentional, conscientious, and constant encouragement of internal sources for selfdevelopment.

The state policy, which is directed to the adaptation of the educational system to modern conditions of the knowledge economy, can facilitate the use of pedagogical innovations. This requires, first of all, the creation of incentives for the use the information technology in the learning process for better adaptation of future managers to the latest requirements of professional activity. The specific mechanisms of state policy that can contribute to the achievement of defined goals are the following: - public education order that can be distributed both to the public sector of education that is absolutely necessary and to the commercial sphere, where private educational organizations will receive certain state support, including direct financing, investments, institutional improvement, especially preferential conditions in the case of ordering from the government authorities to prepare management specialists;

- tax regulation for selective influence on educational organizations. First of all, it concerns organizations of secondary vocational education, as well as higher education and organizations of additional education. In our opinion, the state may and should carry out differentiated taxation and reduce taxes to educational organizations that ensure priority in the realization of general national programs for the training of management specialists both for business and for spheres that provide outbreaks in science, culture, etc.; - providing educational institutions that implement general national training programs for managers, privileged loans that will be provided for a longer than usual term, and at lower interest rates or on easy credit terms. The mechanisms of credit regulation are well known, so we would not go into details of this rather well-known instrument;

- the realization of means of coordinated institutional support in the education sphere. In this context, deserves the support the idea of creating educational clusters, which will be an effective form, that will ensure the unity of state regulation objects since such clusters 
can be key areas, to which the regulatory influence of the state will be directed;

- direct state investments in the sphere of education focused on concrete solutions in the sphere of realization of state educational programs;

- the intensification of organizational efforts is aimed at developing programs of public-private partnership, which are actively developing in the field of education.

Finally, it should be noted that government policy for the implementation of social and pedagogical innovations may be associated with a number of difficulties (lack of funds, conservatism in the educational sphere, lack of technological development).

\section{Conclusions}

The formation of a global knowledge economy has greatly changed the requirements for the content and quality of professional training of managers in modern times, facilitated the growth of the requirements for all aspects of a manager's personality. This causes the necessity for development and practical implementation of social and pedagogical innovations (fundamentally new means and methods of interaction during education) that cover all aspects of the didactic process: the forms of organization of educational process, the content and technology of teaching, educational and cognitive activity, etc. The basic directions of introduction of social and pedagogical innovations in order to improve the process of professional and personal formation of managers might become: inclusion to the system of professional training forms, methods and technologies that teach to perform practically managerial functions under different market conditions; implementation of out-ofclass forms of practical work that develops managerial thinking; expansion of personality developing space by the providers of educational services through the organization of continuous industrial practices. Projecting, modelling, research and creative activity are considered by us as the most important social and pedagogical innovations for the development of economic knowledge.

At the same time, training of managers should develop a complex of both professional and personal qualities in order to enable future managers not only qualitatively use the acquired skills but also independently master new knowledge, create innovations that will have the potential for further commercialization.

\section{References:}

Bereka, V. Ie. (2009). Implementation of innovative technologies in the system of education managers training. Pedahohichnyi dyskurs, 6, 19-23. (in Ukrainian)

Dusi, P., Messetti, G., Steinbach M. (2014). Skills, Attitudes, Relational Abilities \& Reflexivity: Competences for a Multicultural Society. Procedia - Social and Behavioral Sciences, 112, 538-547.

Elkin, M. V. (2013). The role of innovation in the management of training of an educational institution manager. Pedahohika formuvannia tvorchoi osobystosti u vyshchii i zahalnoosvitnii shkolakh, 30, 159-162. (in Ukrainian)

Grant, S. (2005). Teaching and Assessing Skills in Economics. Cambridge University Press.

Koval V., Polyezhaev Y., Bezkhlibna A. (2018). Communicative competences in enhancing of regional competitiveness in the labour market. Baltic Journal of Economic Studies, 4(5), 105-113. doi: 10.30525/22560742/2018-4-5-105-113

Pikalov, V. L., Hlukha, H. Ya. (2017). Concerning the problems of training modern top managers of business entities. Akademichnyi ohliad, 1(46), 71-82. (in Ukrainian)

Pomyluiko, V. Y. (2017). Development of social and communicative conpetens of adults: psychological and pedagogical conditions for corporate training. Psycholinguistics, 21(1), 138-147.

Pshenychna, L. V. (2016). Training the manager of innovative development of education: professional and personal self-improvement. Pedahohichni nauky: teoriia, istoriia, innovatsiini tekhnolohii, 9, 137-150. (in Ukrainian)

Rezvan, O. (2014). The role of emotions in the development of a future specialist's professional and reflective views. Austrian journal of Humanities and Social Sciences, 2, 132-136.

Seliverstova, N. I. (2010). Training of managers in higher education: theoretical and pedagogical aspect. Zaporizhzhia: ZNU. (in Ukrainian)

Shymko, V. A. (2017). Character analysis of oral activity: contact profiling. Psycholinguistics, 21(1), 186-202.

State Statistics Service of Ukraine (2018). Scientific and innovative activity in Ukraine. Retrieved from: http://www.ukrstat.gov.ua (in Ukrainian)

Tereshchenko, M. M. (2016). Problems of modernization of innovation managers training in the context of reforming the education system in Ukraine. Hileia: naukovyi visnyk, 115, 329-333. (in Ukrainian)

Vorona, P. V. (2017). Methodological peculiarities of management of innovative projects in the content of manager training for management of innovation activity. Vytoky pedahohichnoi maisternosti. Seriia: Pedahohichni nauky, 20, 48-53. (in Ukrainian)

World Bank (2018). The World Bank data by indicator: Science \& Technology. Retrieved from: https://data.worldbank.org/indicator

Zhukov, S. A., Kobal, M. V. (2017). Improving the effectiveness of training managers in an innovative economy through interactive methods. Visnyk ekonomichnoi nauky Ukrainy, 2, 37-43. (in Ukrainian) 